\title{
PENGEMBANGAN BAHAN AJAR EVALUASI PEMBELAJARAN MATERI TAKSONOMI TUJUAN UNTUK MENINGKATKAN KOMPETENSI PEDAGOGIK DAN SOFT SKILL MAHASISWA PENDIDIKAN ADMINISTRASI PERKANTORAN
}

\author{
Tauada Silalahi, Gartima Sitanggang
}

Surel: tauadasilalahi@gmail.com

\begin{abstract}
The problem in this research is the lack of teaching materials in the form of modules as mandatory handling of students in following the evaluation lesson, the students need the module as the mandatory handles used in group discussions, on the topic of the material in each face to face. This research was conducted in Department of Economic Education Prodi. Office Administration Faculty of Economics Unimed, this type of research is development research by following model of ADDIE with stages of Analysis, Design, Development, Implementation, and Evaluation, but stages done in this research is still limited to needs analysis, design, and development, and evaluation is expected in subsequent research in 2018, as well as on the implementation of next year's student evaluation learning.
\end{abstract}

Keywords: Instructional Material Form of Learning Evaluation Module.

\begin{abstract}
ABSTRAK
Masalah dalam penelitian ini adalah kurangnya bahan ajar berupa modul sebagai pegangan wajib mahasiswa dalam mengikuti pembelajaran evaluasi, mahasiswa membutuhkan modul sebagai pegangan wajib yang digunakan dalam berdiskusi kelompok, terhadap topik materi dalam setiap tatap muka. Penelitian ini dilaksanakan di Jurusan Pendidikan Ekonomi Prodi. Administrasi Perkantoran Fakultas Ekonomi Unimed, jenis penelitian ini adalah Penelitian pengembangan dengan mengikuti model ADDIE dengan tahapan Analysis, Design, Development, Implementasi, dan Evaluation, namun tahapan yang dilakukan dalam penelitian ini masih terbatas pada Analisis kebutuhan, Design, dan development, sedangkan tahap implementasi dan evaluasi diharapkan pada penelitian selanjutnya tahun 2018, sekaligus pada pelaksanaan pembelajaran evaluasi mahasiswa tahun berikutnya.
\end{abstract}

Kata kunci: Bahan Ajar Berupa Modul Evaluasi Pembelajaran.

\section{PENDAHULUAN}

Guru sebagai pendidik harus berusaha untuk menjadi fasilitator dengan menyediakan bahan ajar dan memanfaatkannya dengan baik. Bahan ajar merupakan komponen penting dalam pembelajaran. Bahan ajar dalam peranannya sebagai pemberi informasi sangat dibutuhkan oleh pendidik maupun peserta didik.
Pendidik harus mampu mengolah serta menelaah setiap informasi didalamnya agar dapat diserap secara tepat. Inovasi dalam penggunaan berbagai bahan ajar sangat penting untuk menambah wawasan peserta didik. Kebiasaan penggunaan bermacam-macam bahan ajar akan mempermudah mengembangan kualitas yang diharapkan. 
Sebuah bahan ajar yang disusun oleh pendidik sendiri pasti akan lebih efektif jika digunakan dalam pembelajaran. Hal tersebut dikarenakan pendidik menguasai isi bahan ajar yang telah dibuat

sehingga dapat menyampaikan dengan menarik, kreatif dan disesuaikan dengan karakteristik peserta didik. Selain itu, peserta didik akan lebih merasa senang dan

tertarik dalam belajar serta mengerjakan soal-soal latihan yang ada dalam bahan ajar tersebut.

Memperhatikan penjelasan di

atas, tampak bahwa tujuan pembelajaran merupakan salah satu

komponen penting dalam pembelajaran, yang di dalamnya dapat menentukan mutu dan tingkat efektivitas pembelajaran.

\section{METODE}

PENELITIAN

Penelitian ini merupakan

jenis penelitian pengembangan. Penelitian pengembangan adalah suatu jenis penelitian yang bertujuan untuk mengembangkan dan menghasilkan suatu produk. Desain pengembangan bahan ajar modul materi pokok taksonomi tujuan hasil belajar dalam penelitian ini diadopsi dari model pengembangan ADDIE yang terdiri atas lima tahap pengembangan yaitu; Analysis, Design, Develop, Implementasi, dan Evaluate.

Subyek penelitian adalah mahasiswa program studi Administrasi perkantoran semester V saat penelitian dilakukan sedang mengikuti perkuliahan evaluasi pembelajaran. Obyek penelitian ini adalah kelayakan modul sebagai bahan ajar dengan pokok materi taksonomi tujuan pembelajaran.

Adapun instrumen penelitian yang digunakan untuk mendapatkan data adalah berupa angket yang mana butir butir item pertanyaannya telah disesuaikan dengan kelayakan yang meliputii; kelayakan isi, kebahasaan, sajian, dan kegrafikan (media), angket ini diberikan kepada dosen yang dianggap ahli masing-masing dibidangnya sebanyak 3 orang,

Selanjutnya

untuk mendapatkan masukan sebagai bahan uji coba kepada mahasiswa sebanyak tiga kali, dimana pertama uji coba satu kali satu,. Selanjutnya hasilnya direvisi dan diikuti dengan ujicoba kelompok kecil sebanyak 10 orang, sama dengan uji sebelumnya hasilnya dijadikan sebagai bahan untuk merevisi.

Teknik analisis data dilakukan untuk mendapatkan produk modul yang berkualitas yang memenuhi aspek kevalidan, kepraktisan, dan keefektifan. Langkah-langkah dalam menganalisis criteria kualitas produk yang dikembangkan adalah sebagai berikut.

\section{HASIL PENELITIAN DAN PEMBAHASAN}

Sesuai dengan jenis penelitian ini adalah merupakan penelitian pengembangan, dimana jenis penelitian ini bertujuan untuk mengembangkan dan menghasilkan suatu produk. Adapun yang menjadi 
produk penelitian ini adalah berupa modul dengan pokok materi taksonomi tujuan pembelajaran bidang kognitif, sebagai bahan ajar untuk mata kuliah evaluasi pembelajaran. Modul pembelajaran disusun berdasarkan prinsip-prinsip pengembangan suatu modul, meliputi analisis kebutuhan, pengembangan desain modul, implementasi, penilaian, evaluasi dan validasi, serta jaminan kualitas

Analisis yang dilakukan adalah untuk mengetahui kebutuhan untuk menentukan masalah dan solusi yang tepat dan menentukan kompetensi mahasiswa, dalam hal ini ada tiga fokus analisis yang dilakukan, yaitu analsis kurikulum, analisis karakter mahasiswa, dan analisis pengembangan modul.

Struktur Kurikulum Prodi

Administrasi

Perkantoran

Pelaksanaan proses belajar mengajar program studi Pendidikan Administrasi Perkantoran menerapkan kurikulum berbasis kompetensi dengan KKNI sesuai dengan kebutuhan pasar tenaga kerja. Mahasiswa dapat menyelesaikan dengan menempuh minimal 144 SKS. Mata Kuliah Wajib 100 SKS, dan Mata Kuliah Pilihan 44 SKS dengan Jumlah Total 144 SKS. Capaian Pembelajaran mata kuliah evaluasi pembelajaran:

Mahasiswa memiliki Kompetensi pedagogik khususnya Evaluasi Pembelajaran. (Ambil dari Capaian Pembelajaran (LO) Prodi Masingmasing)

\section{Kompetensi/ Kemampuan Setiap Tahap Pembelajaran:}

a. Mendeskripsikan gambaran/ruang lingkup materi kuliah (kontrak kuliah).

b. Membedakanpengukuran, pengujian, penilaian, dan evaluasi.

c. Mendeskripsikan teori, prinsip, dan prosedur/ teknik evaluasi pembelajaran.

d. Membedakan tiga ranah taksonomi hasil belajar

e. Mengenali dan membedakan teknik tes dan teknik non tes.

f. Menentukan teknik tes yang sesuai dengan tujuan pelaksanaan evaluasi

g. Menyusun dan melaksanakan tes proses dan hasil pembelajaran.

h. Menentukan skala pengukuran instrument tes dan non tes

i. Mengidentifikasidataskor mentah hasil pengukuran instrumen

j. Menganalisis skor mentah menjadi nilai berdasarkan PAN, PAP dan Kompetensi

k. Mendeskripsikan dan menentukan ciri-ciri instrumen tes dan non tes yang layak digunakan.

1. Menganalisis instrumen/item tes berdasarkan tingkat kesukaran, daya pembeda, dan distraktor.

m. Menganalisis instrumen/item tes berdasarkan teknik validitas,

n. Menganalisis instrumen/item tes berdasarkan teknik reliabilitas.

o. Menentukan/mengambil keputusan atas hasil evaluasi yang dilakukan. 
p. Melakukan refleksi atas evaluasi pembelajaran/Ujian akhir.

Indikator keberhasilan mahasiswa dalam mata kuliah evaluasi pembelajaran

Nilai akhir mahasiswa sebagai akumulasi aspek penilaian diatas adalah:

Nilai $=(25 \times F 1)+(25 \times F 2)+(30 \times F 3)+(20 x F 4)$

Keterangan hasil analisis nilai, Nilai A : $90-100$ Nilai B : 80 $-89$

Nilai c : $70-79$

Nilai E : $0-69$

\section{Analisis Karakter Mahasiswa}

Karakter mahasiswa sebagai produk yang dihasilkan prodi administrasi perkantoran tentu tidak terlepas dari visi dan misi yang telah ditetapkan terlebih dahulu, adapun visi dan misi tersebut adalah sebagai berikut.

\section{Visi Program Studi}

Menghasilkan sumber daya manusia yang profesional, memiliki keunggulan kompetitif, berdaya saing tinggi, memiliki wawasan global serta menguasai ilmu pengetahuan dan teknologi di bidang pendidikan administrasi perkantoran dalam membangun masyarakat Indonesia yang maju, demokratis dan sejahtera berdasarkan Pancasila.

Misi Program Studi

a. Melaksanakan sistem pembelajaran yang profesional dengan terus mengembangkan berbagai sumber daya pembelajaran dan relevansi muatan kurikulum dengan kebutuhan dunia bisnis yang diimbangi dengan akhlak mulia, wawasan wirausaha dan wawasan global.

b. Melaksanakan peningkatan mutu x1pendidikan dan pengajaran, penelitian dan pengabdian kepada masyarakat yang profesional dengan terus mengembangkan sumber daya staf.

c. Meningkatkan mutu proses belajar mengajar/perkuliahan baik secara akademis, konseptual maupun faktual.

d. Meningkatkan mutu pemantauan dan evaluasi hasil/prestasi belajar mahasiswa secara lebih cermat dan berkelanjutan.

e. Menjalin kerjasama yang baik dengan instansi pemerintah maupun dunia bisnis dalam dan luar negeri sebagai mitra kerjasama di bidang pendidikan dan bisnis yang saling menguntungkan.

\section{Tujuan Program Studi Pendidikan} Administrasi Perkantoran

a. Menghasilkan tenaga kependidikan yang profesional di bidang kependidikan administrasi perkantoran pada tingkat SLTP, SMU dan SMK.

b. Mempersiapkan tenaga ahli dan terampil untuk mendidik calon wirausaha di bidang administrasi perkantoran. 


\section{Profil Lulusan}

Profil dan profesi lulusan program studi yang diharapkan sesuai KKNI adalah sebagai berikut:
a. Guru Administrasi Perkantoran SMK.
b. Peneliti Bidang Pendidikan.
c. Administrator.
d. Wirausaha.
e. Manajerial Bidang Administrasi Perkantoran.

\section{Capaian Pembelajaran Program Studi (PLO).}

Program Studi Pendidikan Administrasi Perkantoran memiliki Capaian Pembelajaran yang berbeda dengan program studi yang berdekatan secara keilmuan seperti Pendidikan Akuntansi, Pendidikan Ekonomi Koperasi dan Pendidikan Tata Niaga. Beberapa perbedaan diantaranya program studi adalah sebagai berikut:

a. Analisis Muatan Kompentensi Dasar Admistrasi perkantoran fokusnya adalah untuk penguasaan alatalat perkantoran dilingkungan perkantoran.

b. Analisis Standar Kompetensi Lulusan, kompetensi inti dan kompetensi dasar sehingga implementasi dalam berbagai strategi pembelajaran akan berbeda termasuk dalam menuangkan dalam pembuatan RPP. Pembekalan khusus terkait dengan kemampuan professional yang berbeda sesuai dengan karakteristik program studi.

\section{Gelar Lulusan}

Program Studi pendidikan Administrasi Perkantoran adalah Prodi yang siap melahirkan tenagatenaga profesional, baik sebagai pendidik maupun non tenaga pendidikan yang terampil. Tenaga pendidik profesional bergelar S.Pd(sarjana pendidikan), khususnya tenaga pendidik di SMK jurusan/kompetensi keahlian Administrasi perkantoran

Disamping itu, para lulusan juga berkesempatan menjadi tenaga ahli diluar pendidikan dan mampu melaksanakan kegiatan Perkantoran secara profesional, memiliki kompetensi kepribadian dan sosial yang menjadi modal dasar dalam melaksanakan kegiatan wirausaha.

Kompetensi lulusan S1 Pendidikan Administrasi Perkantoran berada pada level 6 KKNI, berupa kemampuan sebagai berikut:

a. Mengaplikasikan bidang keahliannya dan memanfaatkan ipteks pada bidangnya dalam penyelesaian masalah serta mampu beradaptasi terhadap situasi yang dihadapi,

b. Menguasai konsep teoritis bidang pengetahuan tertentu secara umum dan konsep teoritis bagian khusus dalam bidang pengetahuan tersebut secara mendalam serta mampu memformulasikan penyelesaian masalah prosedural,

c. Mengambil keputusan yang tepat berdasarkan analisis informasi dan data dan mampu memberikan petunjuk dalam 


\author{
memilih berbagai alternatif \\ solusi secara mandiri dan \\ kelompok, dan \\ d. Bertanggung jawab pada \\ pekerjaan sendiri dan dapat \\ diberi tanggung jawab atas \\ pencapaian hasil kerja \\ organisasi.
}

Lulusan S1 Program Studi Pendidikan Administrasi Perkantoran harus memiliki kemampuan antar lain: mengaplikasikan aktivitas bidang Administrasi Perkantoran dengan memanfaatkan temuan ipteks dalam menyelesaikan masalah yang dihadapi; menguasai teori Administrasi, khususnya Administrasi Perkantoran serta memecahkan masalah yang dihadapi secara prosedural; mengambil keputusan yang tepat baik dalam posisinya sebagai individu maupun kelompok; dan bertanggungjawab atas tercapainya tujuan organisasi. Berbagai kemampuan tersebut harus tercover dalam kurikulum Program

Studi Pendidikan Administrasi Perkantoran.

\section{Analisis Pengembangan Modul} Pada tulisan ini untuk melihat kelayakan isi modul, terlebih dahulu telah ditetapkan kurikulum untuk mata kuliah evaluasi pembelajaran di fakultas ekonomi khususnya jurusan pendidikan ekonomi pada keahlian

program studi administrasi perkantoran. Adapun kurikulum yang diterapkan semenjak tahun angkatan 2015 adalah kurikulum KKNI, kurikulum tersebut telah dianalisis sebelumnya dan distribusi mata kuliah serta silabus dan rancangan perkuliahan semester (RPS) sebagaimana terlampir pada bagian akhir penelitian ini.

Sedangkan untuk kelayakan bahasa, dilakukan penelusuran melalui instrumen angket baik kepada mahasiswa yang sedang mengikuti perkuliahan, dan juga

kepada rekan dosen sesama pengampu mata kuliah evaluasi dalam satu KDBK yang sama di fakultas ekonomi. Respon yang diperoleh dijadikan untuk memperbaiki dan merevisi modul yang dihasilkan sebagai produk penelitian. Sebagaimana dengan analisis terhadap bahasa demikian juga dengan aspek penyajian, dan kegrafikan sekaligus menjadi itemitem dalam indikator instrumen

angket yang disusun untuk mendapatkan respon mahasiswa dan dosen pengampu sebagai ahli di bidang evaluasi pembelajaran.

\section{Design}

Dalam rangka untuk mempersiapkan penyusunan modul, langkah pertama yang dilakukan adalah melengkapi referensi sebagai literatur, yang menjadi landasan atau acuan terhadap penetapan materi maupun aspek kebahasaan, kegrafikan, dan teknik penyajian. Langkah selanjutnya diikuti dengan penetapan peta kebutuhan terhadap modul, dalam hal ini mahasiswa di prodi administrasi perkantoran yang sedang mengikuti mata kuliah evaluasi pembelajaran pada saat 
penelitian dilakukan ada sebanyak 200 orang, yang terdiri dari dua angkatan, yakni tahun angkatan 2016 (kurikulum KKNI) dan angkatan 2015 masih menggunakan kurikulum sebelumnya.

Setelah melengkati fererensi dan menetapkan peta kebutuhan, langkah selanjutnya adalah menetapan desain modul antara lain; menetapkan judul, menentukan desain, dan penyusunan desain instrumen. Adapun hal tersebut adalah seperti berikut ini.

Judul modul: Pengembangan bahan ajar evaluasi pembelajaran untuk meningkatkan kompetensi mahasiswa pendidikan Administrasi perkantoran.

\section{Desain modul:}

Pengembangan suatu desain modul dilakukan dengan tahapan yaitu menetapkan strategi pembelajaran dan media, memproduksi modul, dan mengembangkan perangkat penilaian. Dengan demikian, modul disusun berdasarkan desain yang telah ditetapkan. Dalam konteks ini, desain modul ditetapkan berdasarkan Rencana Pelaksanaan Pembelajaran (RPP) yang telah disusun oleh dosen. Desain penulisan modul yang dimaksud di sini adalah Rencana Pelaksanaan Pembelajaran (RPP) yang telah disusun oleh guru/dosen. Di dalam RPP telah memuat strategi pembelajaran dan media yang digunakan, garis besar materi pembelajaran dan metoda penilaian serta perangkatnya. Dengan demikian, RPP diacu sebagai desain dalam penyusunan/penulisan modul.

\section{Desain instrumen}

Instrumen yang digunakan untuk mendapatkan tanggapan sebagai masukan perbaikan modul, didasarkan pada indikator elemen mutu modul. Adapun sebagai reponden adalah mahasiswa yang sedang mengikuti perkuliahan, dosen pengampu mata kuliah yang sama, dan pakar/ahli di bidang pendidikan.

Untuk menghasilkan modul pembelajaran yang mampu memerankan fungsi dan perannya dalam pembelajaran yang efektif, modul perlu dirancang dan dikembangkan dengan memperhatikan beberapa elemen

yang mensyaratkannya, yaitu: kelayakan isi, kelayakan penyajian, kelayakan bahasa, dan kelayakan materi.

\section{Development}

Pada tahap ini dikembangkan modul evaluasi pembelajaran pada pokok materi taksonomi tujuan hasil belajar yang didasarkan atas masukan desain yang telah disusun, adapun evaluator sebagai responden yang dijadikan sebagai ahli dalam penelitian ini, untuk ahli materi evaluasi pembelajaran yaitu Drs. Thamrin, M.Si., beliau telah menjadi dosen pengampu mata kuliah evaluasi pembelajaran di jurusan pendidikan ekonomi selama lebih dari 10 tahun, dan saat ini sedang mengikuti pendidikan program S-3 dengan jurusan Manajemen 
Pendidikan di Unimed. Sedangkan ahli kebahasaan dan sajian adalah Dr. Arwansyah M.Si, adalah ketua Jurusan pendidikan Ekonomi di

Fakultas Ekonomi Unimed. Selanjutnya dosen ahli Media dan kegrarikan adalah Dr. Dede Ruslan, MSi., dan merupakan sekretaris di Jurusan Pendidikan Ekonomi Unimed.

\section{Diskripsi Frekuensi Jawaban Dosen Ahli}

Berdasarkan jawaban atas angket yang telah disebarkan, penulis membuat daftar distribusi frekuensi atas jawaban pada skala nilai, seperti berikut:

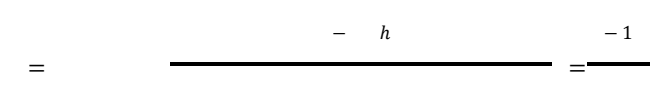

Berdasarkan

hasil

perhitungan di atas, maka diperoleh panjang interval yaitu sebesar 0,80 , sehingga dapat dikategorikan sebagai berikut,

Tabel 1. Kategori Hasil Data

\begin{tabular}{c|l}
\hline \multicolumn{1}{c|}{ Interval } & \multicolumn{1}{|c}{ Kategori } \\
\hline $1,00-1,79$ & $\begin{array}{l}\text { Sangat tidak } \\
\text { Baik/sesuai }\end{array}$ \\
\hline $1,80-2,59$ & $\begin{array}{l}\text { Kurang } \\
\text { baik.sesuai }\end{array}$ \\
\hline $2,60-3,39$ & Cukup \\
\hline $3,40-4,19$ & Baik \\
\hline $4,20-5,00$ & $\begin{array}{l}\text { Sangat } \\
\text { baik/sesuai }\end{array}$ \\
\hline
\end{tabular}

Selanjutnya untuk merespon hasil penilaian dari dosen ahli, penulis melakukan revisi terhadap desain modul evaluasi pembelajaran yang telah didesain sebelumnya. Adapun kategori dari hasil amatan dosen ahli pada dasarnya sudah berada pada kategori baik, namun untuk suatu modul bahan ajar yang diharapkan efektif tentunya masih kurang dan perlu dilakukan revisi. Untuk itu penulis melakukan revisi khususnya berkaitan dengan materi telah ditambahkan kompetensi yang akan dicapai, peta konsep materi,

kaitan materi dengan kemanfaatannya dalam keseharian mahasiswa selaku calon guru.

Berkaitan dengan kebahasaan dan sajian, penulis telah mencoba membaca dan mereview ulang dengan lebih seksama, sehingga kalimat kalimat yang belum sesuai atau masih kurang nyambung secara koheren antar kata, kalimat, maupun paragaraf diperbaiki.

Selanjutnya berkaitan dengan kegrafiakan dan media, penulis telah memperbaiki beberapa item, seperti membuat lebih bervariasi ukuran font, memperbaiki tata letak, yang dan menambah ilustrasi seperti gambar, dan memperbaiki desain tampilan.

\section{Diskripsi Jawaban Mahasiswa}

Berkaitan dengan uji coba yang dilakukan terhadap mahasiswa selaku pengguna langsung modul atau bahan ajar yang disusun, dilakukan dengan tiga tahap, dimana tahap tahap tersebut adalah; pertama 
dilakukan terhadap 3 orang mahasiswa dimana ketiga mahasiswa ini ditentukan dari prestasi yang berbeda yakni; masing masing satu orang mahasiswa yang paling pintar, sedang, dan kurang. Kedua, uji coba dilakukan kepada kelompok mahasiswa secara terbatas yakni sebanyak 8 orang yang tidak terlalu mempertimbangkan latar belakang prestasi, sedangkan uji coba yang ketiga dilakukan kepada kelas reguler yang sedang mengikuti perkuliahan evaluasi pembelajaran berjumlah 38 orang.

Berdasarkan jawaban mahasiswa atas angket yang telah disebarkan, penulis membuat daftar distribusi frekuensi atas jawaban pada skala nilai, seperti berikut:

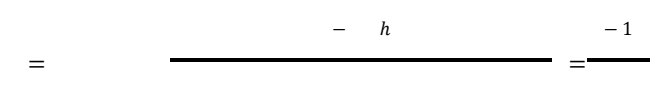

Berdasarkan

hasil perhitungan di atas, maka diperoleh panjang interval yaitu sebesar 0,75 , sehingga dapat dikategorikan sebagai berikut:

Tabel 2. Interval Kategori Hasil data Mahasiswa

\begin{tabular}{c|l}
\hline Interval & \multicolumn{1}{c}{ Kategori } \\
\hline $1,00-1,74$ & $\begin{array}{l}\text { Sangat tidak } \\
\text { Baik/sesuai }\end{array}$ \\
\hline $1,75-2,49$ & $\begin{array}{l}\text { Kurang } \\
\text { baik.sesuai }\end{array}$ \\
\hline $2,50-3,24$ & Cukup \\
\hline $3,25-4,10$ & Baik \\
\hline
\end{tabular}

Selanjutnya

untuk menginterpretasi hasil tanggapan 3 orang mahasiswa, yang terdiri dari tiga kategoori prestasi tersebut, dapat dilihat seperti berikut ini.

Tabel 3. Rekapitulasi skor data Mahasiswa

\begin{tabular}{c|c|c|c|c|c}
\hline No. & Kategori & Perhitungan Skor & Total Skor & $\begin{array}{c}\text { Rata- rata } \\
\text { skor }\end{array}$ & Keterangan \\
\hline 1 & Prestasi tinggi & $5 \times 3+15 \times 4$ & 75 & 3,75 & Baik \\
\hline 2 & $\begin{array}{c}\text { Prestasi } \\
\text { sedang }\end{array}$ & $5 \times 3+15 \times 4$ & 75 & 3,75 & Baik \\
\hline 3 & Prestasi rendah & $2 \times 2+9 \times 3+9 \times 4$ & 67 & 3,35 & Baik \\
\hline
\end{tabular}

Berdasarkan tabel di atas dapat diambil kesimpulan bahwa dari pendapat ketiga mahasiswa yang berasal dari tiga latar belakang pada tingkatan prestasi tersebut adalah menyatakan bahwa modul yang mereka nilai telah berada pada kategori baik, namun beberapa item 
masih perlu diadakan perbaikan. Setelah diadakan perbaikan untuk selanjutnya dilanjutkan lagi uji coba untuk mahasiswa pada kelompok kecil yakni 8 orang tanpa

memperhatikan latar belakang prestasi, hal ini akan menjadi sampel terhadap satu kelas. Berkaitan dengan instrumen yang diisi oleh mahasiswa diadakan sedikit perbaikan yakni dari alternatif jawaban yang disediakan menjadi lebih variatif yakni dengan menambah kategori sangat baik, hal ini dimaksudkan supaya mahsiswa lebih bebas memilih alternatif sesuai dengan penilaiannya. Dasar untuk menginterpretasikan data yang diperoleh jarak interval untuk masing-masing kategori adalah 0,80 sama halnya dengan pedoman interpretasi hasil data terhadap dosen ahli sebelumnya dimana, ada lima alternatif pilihan jawaban, seperti pada tabel berikut.

Tabel 4. Interval Kategori hasil Data

\begin{tabular}{c|l}
\hline \multicolumn{1}{c|}{ Interval } & \multicolumn{1}{c}{ Kategori } \\
\hline $1,00-1,79$ & $\begin{array}{l}\text { Sangat tidak } \\
\text { Baik/sesuai }\end{array}$ \\
\hline $1,80-2,59$ & $\begin{array}{l}\text { Kurang } \\
\text { baik.sesuai }\end{array}$ \\
\hline $2,60-3,39$ & Cukup \\
\hline $3,40-4,19$ & Baik \\
\hline $4,20-5,00$ & $\begin{array}{l}\text { Sangat } \\
\text { baik/sesuai }\end{array}$ \\
\hline
\end{tabular}

Berdasarkan interpretasi terhadap hasil yang diperoleh dari delapan orang mahasiswa terhadap bahan ajar atau modul evaluasi, dapat disimpulkan bahwa sudah berada pada kategori baik, sama halnya dengan hasil pengujian terhadap tiga orang mahasiswa sebelumnya, namun dilihat dari masing-masing

item boleh dikatakan ada peningkatan atau lebih tinggi dari sebelumnya, akan tetapi dilihat dari interval masih berada pada kategori baik.

Sama halnya dengan hasil uji coba dua tahap sebelumnya, setelah uji coba terhadap kelas yang dijadikan sebagai masukan untuk melihat keefektipan dari modul evaluasi pembelajaran sebagai bahan ajar dilakukan analisis sebagai bahan interpretasi untuk mengambil kesimpulan. Adapun hasil yang diperoleh adalah bahwa semua mahasiswa selaku responden yang ditanyakan diperoleh jawaban pada kategori minimal baik, bahkan beberapa orang yakni tujuh orang memberi jawaban dengan rata rata pada kategori sangat baik.

Dengan melihat hasil uji coba yang telah dilakukan sebanyak tiga tahap terhadap mahasiswa, dengan masing masing tahap telah menunjukkan bahwa kualitas bahan ajar sebagai modul evaluasi pembelajaran pada kategori baik, bahkan pada uji coba tahap ketiga telah berada padakategori sangat baik, dengan demikian dapat disimpulkan bahwa modul yang disusun ini telah dapat digunakan sebagai modul sebagai sumber pegangan bagi mahasiswa dalam pembelajaran. 


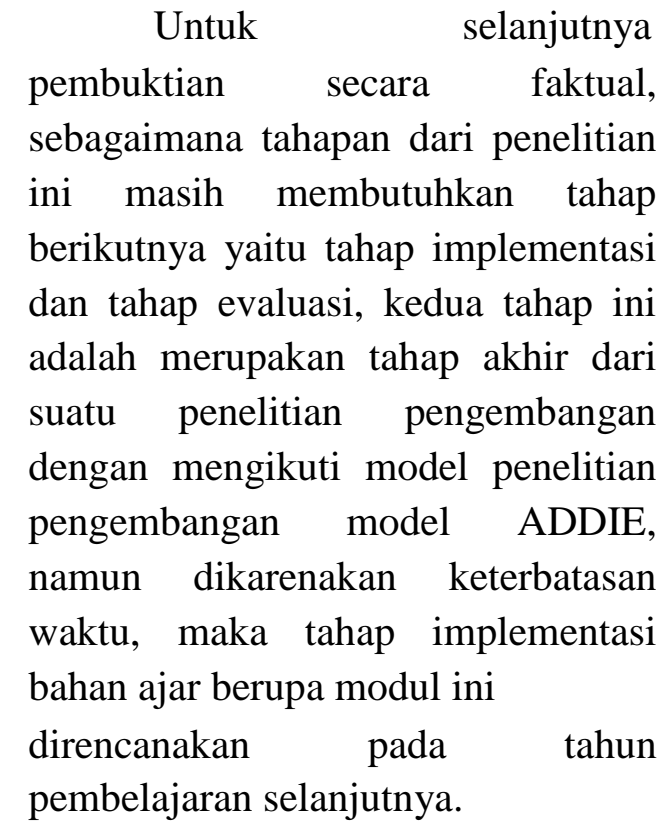

\section{Pembahasan}

Modul pembelajaran disusun berdasarkan prinsip-prinsip pengembangan suatu modul, meliputi analisis kebutuhan, pengembangan desain modul, implementasi, penilaian, evaluasi dan validasi, serta jaminan kualitas

Desain pengembangan modul sebagai bahan ajar pada materi taksonomi tujuan hasil belajar dalam penelitian ini diadopsi dari model pengembangan ADDIE yang terdiri atas lima tahap pengembangan yaitu

Analysis, Design, Develop, Implementation, dan Evaluate. Namun dalam penelitian ini kelima tahap belum dilakukan keseluruhannya, mengingat waktu penelitian tidak mencukupi, hanya empat bulan termasuk menyusun

proposal. Sementara kegiatan meliputi ujicoba yang sampai tiga tahap secara berkesinambungan tentunya membutuhkan waktu. Oleh karena itu penelitian ini hanya sampai pada pengembangan, dalam hal ini sampai produk penelitian berupa bahan ajar atau modul evaluasi pembelajaran terselesaikan.

Selanjutnya untuk tahap implementasi, dan evaluasi diharapkan dilakukan pada penelitian selanjutnya. Penelitian implementasi ini dimaksudkan untuk melihat sampai dimana pengaruh penggunaan modul atau bahan ajar dapat meningkatkan prestasi mahasiswa dibandingkan dengan tidak menggunakan modul.

Berdasarkan hasil data yang diperoleh sebagaimana ujicoba sebelumnya juga dilakukan perbaikan, dimana melalui perbaikan diperoleh peningkatan rata rata, walaupun masih pada kategori yang sama yakni kategori baik. Dengan demikian dapat disimpulkan bahwa penyusunan bahan ajar sebagai modul evaluasi pembelajaran untuk sampai pada tahap uji ini, layak digunakan, namun untuk lebih meyakinkan efek atau pengaruh penggunaan modul dimaksud, masih diperlukan penelitian lanjutan yakni pada tahap implementasi dan evaluasi. Penelitian ini diharapkan dilakukan pada penelitian selanjutnya, sebagaimana penelitian ini adalah merupakan penelitian pengembangan.

\section{SIMPULAN}

Berdasarkan hasil dan pembahasan penelitian yang telah dilakukan, dapat disimpulkan hasilnya antara lain seperti berikut: 
a. Mahasiswa membutuhkan bahan ajar berupa modul sebagai pedoman maupun pegangan wajibdalammengikuti perkuliahan evaluasi pembelajaran.

b. Penelitian ini telah menghasilkan produk bahan ajar berupa modul yang penyusunannya didasarkan atas analisis kebutuhan mahasiswa.

c. Penyusunan produk modul ini dilakukan dengan terlebih dahulu melibatkan dosen ahli untuk memberikan masukan atas desain awal modul.

d. Mahasiswatelahdiminta memberikanmasukanatas keberadaan desain modul melalui tahap one to one, kelompok delapan, dan diakhiri kelas yang sedang diampu pada semester penelitian ini dilakukan.

\section{DAFTAR RUJUKAN}

Anas, Sudijono. 2010. Pengantar Evaluasi Pendidikan. Jakarta: Raja Grafindo Persada.

Arikunto, Suharsimi. 2003. Dasardasar Evaluasi Pendidikan. Jakarta: Bumi Aksara.

Depdiknas. 2003. Materi Pelatihan

Peningkatan Kemampuan Guru Dalam Penyusunan dan Penggunaan Alat Evaluasi Serta Pengembangan Sistem Penghargaan Terhadap Siswa, Jakarta: Direktorat PLPDitjen Dikdasmen.
Hamalik, Oemar. 2009. Dasar-dasar Pengembangan Kurikulum, Bandung: Remaja Rosdakarya. Mardapi, Djemari. 2004. Penyusunan Tes Hasil Belajar. Yogyakarta: Program Pascasarjana UNY.

Kemp,J.E, Morrison, G.R., and Ross, S.M. 1994. Designing Effective Instruction. New York:

Maxwell Macmilan

International.

Pusat Kurikulum. Model Penilaian Berbasis Kelas Kurikulum Berbasis Kompetensi Sekolah Menengah Kejuruan. Jakarta: Depdiknas.

Sudijono, Anas. 2011. Pengantar Evaluasi Pendidikan. Jakarta: Raja Grafindo Persada.

Sudjana, Nana. 2008. Penilaian Hasil dan Proses Belajar Mengajar. Bandung: Remaja Rosdakarya.

Suparman, Atwi. 2001. Desain Instruksional, Jakarta: PAUPPAI, Universitas Terbuka.

Uno, Hamzah. 2008. Perencanaan Pembelajaran. Jakarta: Bumi Aksara.

Wirawan, Bahrudin. 2009. Teknik Evaluasi pendidikan dalam praktik, Jakarta: Gramedia.

Zaenal, Arifin. 2011. Evaluasi Pembelajaran Prinsip Teknik Prosedur. Bandung: Remaja Rosdakarya. 